\title{
Sistem Predasi dalam Dinamika Populasi
}

\author{
Steven Donggio \\ (Komunitas Konservasi Indonesia, \\ email: steven.donggio@gmail.com)
}

\begin{abstract}
Abstrak
Paper ini berkaitan dengan system predasi dalam Dinamika Populasi. Paper ini disusun dalam memperluas ilmu tentang dasar dan manfaat pembelajaran dinamika populasi berdasarkan pengamatan dari berbagai sumber informasi yang dijadikan sebagai referensi. Semoga paper ini dapat memberikan wawasan yang lebih luas dan menjadi sumbangan pemikiran kepada pembaca khususnya para mahasiswa. Predasi merupakan hubungan antara predator (pemangsa) dan prey (mangsa). Pada predasi sendiri terdapat dua model yang mendeskripsikan interaksi dua spesies terdiri dari predator dan prey merupakan model predator-prey. Model predator- prey sederhana ini diperkenalkan Lotka- Voltera yang kemudian di modifikasi oleh Leslie Gower. Hubungan antar spesies dapat dikelompokkan menjadi netralisme, mutualisme, parasitisme, predatorisme, kooperasi, kompetisi, komensalisme, dan antagonis.
\end{abstract}

Kata Kunci: Sistem Predasi, Mangsa, Pemangsa.

\begin{abstract}
This paper deals with the predation system in Population Dynamics. This paper is structured to broaden knowledge about the basis and benefits of studying population dynamics based on observations from various sources of information that are used as references. Hopefully this paper can provide broader insights and contribute ideas to readers, especially students. Predation is a relationship between predator (predator) and prey (prey). In predation itself there are two models that describe the interaction of two species consisting of predators and prey which is a predator-prey model. This simple predator-prey model was introduced by Lotka-Voltera which was later modified by Leslie Gower. Relationships between species can be grouped into neutralism, mutualism, parasitism, predatorism, cooperation, competition, commensalism, and antagonism.
\end{abstract}

Keywords: Predation System, Prey, Predator.

\section{PENDAHULUAN}

\subsection{Latar Belakang}

Dalam kehidupan setiap makhluk hidup tidak dapat terlepas dengan yang namanya interaksi. Interaksi merupakan suatu jenis tindakan yang terjadi ketika dua atau lebih objek mempengaruhi atau memiliki efek satu sama lain. Salah satu interaksi yang terjadi adalah interaksi antara mangsa dan pemangsa, yang sering disebut dengan interaksi predasi. 


\section{Artikel Ilmiah Nasional}

Predasi merupakan hubungan antara predator (pemangsa) dan prey (mangsa) (Campbell dan Reece 2004). Menurut Ramlawati dkk (2017), predasi yaitu interaksi antara pemangsa dan mangsa.

Apabila tidak ada interaksi yang terjadi pada dua spesies tersebut dan lingkungan tidak membatasi maka populasi prey akan meningkat tak terbatas yang disebut dengan model pertumbuhan eksponensial. Adapun model pertumbuhan logistik yang merupakan model pertumbuhan populasi dengan kapasitas daya tampung (carrying capacity). Kapasitas daya tampung (carrying capacity) merupakan batas atas yang dapat dicapai oleh ukuran populasi, dimana jumlah populasi itu tidak lagi dapat didukung oleh sarana, sumberdaya, dan lingkungan yang ada (Toaha, 2013).

Model yang mendeskripsikan interaksi dua spesies terdiri dari predator dan prey merupakan model predator-prey. Model ini terdiri dari model laju perubahan populasi predator dan model laju perubahan populasi prey. Model predator-prey sederhana ini diperkenalkan Lotka-Voltera dengan asumsi dasar bahwa masing- masing spesies mengalami pertumbuhan secara eksponen, pengembangan model ini menginvestigasi pertumbuhan logistik satu spesies ketika spesies yang lain tidak ada. Model sederhana ini kemudian mengalami banyak modifikasi. Salah satunya Leslie dan Gower (1969) yang memodifikasi model predator-prey dengan memberikan adanya rasio/ perbandingan Antara populasi predator dan populasi prey yang mempengaruhi pertumbuhan populasi predator.

\subsection{Rumusan Masalah}

Adapun rumusan masalah pada makalah ini, antar lain:

1. Apa yang dimaksud predasi?

2. Apa yang dimaksud dengan model Lotka-Volterra?

3. Apa yang dimaksud degan model Leslie Gower?

4. Bagaimana contoh kasusnya?

\subsection{Tujuan}

Adapun tujuan dari pembuatan makalah ini yaitu untuk mengetahui mengenai predasi, model Lotka-Voltera, model Leslie Gower, dan contoh kasusnya. 


\section{TINJAUAN PUSTAKA}

\subsection{Predasi}

Salah satu bentuk interaksi yang terjadi di dalam ekosistem adalah predasi. Predasi merupakan hubungan antara predator (pemangsa) dan prey (mangsa) (Campbell dan Reece 2004). Menurut Ramlawati dkk (2017), predasi yaitu interaksi antara pemangsa dan mangsa. Hubungan atau interaksi ini sangat erat sebab tanpa mangsa, predator tidak dapat hidup. Predasi merupakan persaingan antara ikan predator dalam memperebutkan ikan prey (mangsa) demi mempertahakan hidupnya (Toaha, 2013).

- Pemangsa (predator): Dalam hal ini pemangsa memakan mangsa, tetapi mangsa memakan makanan lain Tanpa adanya mangsa, populasi menurun dan lama kelamaan akan musnah.

- Mangsa (prey): Dalam hal ini mangsa dimakan oleh pemangsa. Mangsa memakan makanan lain yang ada di alam dalam habitat tempat hidupnya Tanpa adanya pemangsa, populasinya tumbuh terus secara tak terbatas. Dalam hal ini dianggap bahwa sumberdaya pendukung pertumbuhan (makanan) tersedia secara takterbatas. Apabila populasi pemangsanya lebih sedikit dibanding dengan populasi mangsa,

maka populasi mangsanya berkembang lebih cepat. Hal ini akan mengakibatkan sumberdaya alam yang dimakan oleh mangsa akan lebih cepat berkurang daripada kecepatan pertumbuhannya. Sebaliknya apabila populasi pemangsanya jauh lebih besar dibanding dengan populasi mangsa, maka populasi mangsanya semakin cepat berkurang (dibanding pertumbuhannya), bahkan lama- kelamaan akan menunju kepunahan. Ini akan berakibat pula populasi pemangsanya akan berkurang juga dan juga lama kelamaan akan punah.

Dengan adanya predasi maka populasi dari mangsa akan terkontrol dan untuk mengontrol tingkat predasi agar tidak menyebabkan terjadinya kepunahan pada kedua spesies tersebut, maka diberikan perlakuan pemanfaatan populasi mangsa secara teratur, jika dimanfaatkan terlalu tinggi maka akan menyebabkan kepunahan (Didiharyono, 2016). Salah satu bentuk interaksi pada makhluk hidup yaitu saling memangsa antara spesies satu dengan lainnya demi kelangsungan hidupnya. Dalam matematika model tersebut disebut dinamika model prey-predator.

Menurut Iswanto (2012), dalam model prey-predator terdapat dua jenis sistem 


\section{Artikel Ilmiah Nasional}

interaksi. Pertama yaitu jenis sistem interaksi antara dua speesies yang salah satunya dimangsa. Lalu yang kedua yaitu adanya persaingan dalam memperebutkan satu spesies mangsa. Dalam kasus ini, interaksi tersebut yaitu ikan yang lebih kecil merupakan ikan prey diburu oleh predator, dengan predator pertama yaitu ikan yang lebih kecil dan predator yang kedua yaitu pemanfaatan yang dilakukan oleh nelayan.

\subsection{Model Lotka-Volterra}

Menurut Dwaradi (2011), model Lotka-Volterra juga dikenal sebaga model preypredator (mangsa-pemangsa). Model ini secara umum diasumsikan berdasarkan asumsi sebagai berikut:

a. Dalam keadaan tanpa prey, lingkungan hidup populasi prey sangat ideal sehingga perkembangan tidak terbatas

b. Pertumbuhan prey juga ideal, kecuali terdapat kendala makan

c. Laju mangsa proporsional dengan laju pertemuan antara prey dan predator

d. Laju kematian predator adalah konstan, tidak terpengaruh terhadap kepadatan dan umur prey

e. Efesiensi predator tidak bergantung umur prey predator

f. Efesiensi penggunaan prey sebagai makanan predator untuk bereproduksi adalah konstan dan tidak tergantung umur dan kepadatan predator

g. Gerakan dan kontak prey dan predator bergantung secara acak. Setiapindividu prey memiliki peluang yang sama untuk dimangsa

h. Waktu yang digunakan predator untuk memangsa diabaikan

i. Kepadatan prey tidak mempengaruhi peluang pemangsaan

j. Kepadatan predator tidak mempengaruhi peluang predator untuk memangsa

Model populasi mangsa pemangsa yang berdasarkan kepada model LotkaVolterra adalah salah satu model yang sangat populer dalam matematika biologi. Luckinbill (1973) menunjukkan bahwa populasi mangsa dan pemangsa dapat hidup bersama dengan cara mengurangi frekuensi interaksinya. Danca et al. (1997) menganalisis suatu model mangsapemangsa dengan menggunakan metode analitik dan numerik.

Misalkan $\mathrm{x}=\mathrm{x}(\mathrm{t})$ dan $\mathrm{y}=\mathrm{y}(\mathrm{t})$ menyatakan ukuran populasi mangsa dan pemangsa pada waktu t, maka model laju pertumbuhan populasi mangsa dan pemangsa diberikan oleh sistem persamaan differensial autonomi.

$$
\begin{aligned}
& \frac{d x}{d t}=r x-a x y \\
& \frac{d y}{d t}=-m y+b x y
\end{aligned}
$$


Persamaan dx/dt menggambarkan laju perubahan populasi mangsa per satuan waktu. populasi mangsa bertambah ketika tidak ada pemangsa yang dituliska rx dengan $r$ adalah tingkat pertumbuhan mangsa dan $\alpha$ mengukur laju konsumsi mangsa oleh pemangsa,. Sementara itu persamaan dy/dt menggambarkan laju perubahan populasi pemangsa per satuan populasi pemangsa berkurang ketika tidak ada mangsa yang dituliskan dengan my dimana $\mathrm{m}$ adalah tingkat penurunan pemangsa atau laju kematian populasi pemangsa, b mengukur konversi mangsa yang dikonsumsi ke dalam laju reproduksi pemangsa (Logan 2011).

Menurut Edwards dan Penney (2008), model predator-prey yang paling sederhana adalah model Lotka-Volterra dengan asumsi pertumbuhan prey mengikuti pertumbuhan populasi. Akan tetapi, model tersebut memiliki kelemahan karena populasi tumbuh secara tidak terbatas seiring dengan pertambahan waktu. Pada kenyataannya, suatu populasi tidak dapat bertambah secara terus menerus karena adanya faktor-faktor penghambat pertumbuhan populasi seperti ruang hidup, makanan, maupun lingkungan (Didiharyono \& Irwan, 2019). Kelemahan lainnya yaitu model Lotka-Volterra hanya melibatkan satu predator dan satu prey saja sedangkan pada beberapa ekosistem terdapat predasi yang melibatkan dua predator dengan prey yang sama.

\subsection{Model Leslie Gower}

Model Leslie Gower merupakan salah satu modifikasi dari model Lotka- Voltera, dimana model ini menganggap carrying capacity populasi predator dipengaruhi oleh populasi prey. Model ini mengasumsikan bahwa populasi pemangsa mempunyai hubungan timbal balik dengan kelangkaan populasi mangsa. Model ini mempunyai beberapa asumsi, yaitu:

a. Laju pertumbuhan populasi mangsa dipengaruhi oleh tingkat pertumbuhan populasi mangsa, berkurang karena persaingan antar spesies dan interaksi mangsa dan pemangsa.

b. Laju pertumbuhan populasi pemangsa dipengaruhi oleh tingkat pertumbuhan populasi mangsa, berkurang karena persaingan antar spesies dan interaksi mangsa dan pemangsa. (Sahamony dkk 2016).

Dari beberapa asumsi model mangsa pemangsa Leslie Gower maka diperoleh persamaan:

$$
\begin{aligned}
& \frac{d x(t)}{d t}=\left(r_{1}-b x(t)-\frac{c_{1} y(t-\tau)}{x(t)+K_{1}}\right) x(t), \\
& \frac{d y(t)}{d t}=\left(r_{2}-\frac{c_{2} y(t-\tau)}{x(t-\tau)+K_{2}}\right) y(t),
\end{aligned}
$$




$$
\text { Dengan nilai, } x(0) \geq 0, y(0) \geq 0
$$

Di dalam persamaan, $x$ adalah banyaknya populasi mangsa, $y$ adalah banyakya populasi pemangsa, $r 1$ adalah pertumbuhan mangsa, $b$ adalah tingkat penurunan kompetisi, $c 1$ adalah tingkat penurunan $y$ karena $x, K 1$ adalah daya dukung mangsa, $r 2$ adalah pertumbuhan pemangsa, $c 2$ adalah tingkat penurunan $y$ karena $x$ dan $K 2$ adalah daya dukung pemangsa.

\subsection{Hubungan Antar Spesies}

Secara garis besar menurut Dwidjoseputro (1991) hubungan antar spesies dapat dikelompokkan menjadi beberapa bentuk dasar hubungan, yaitu

- Netralisme yaitu hubungan antara makhluk hidup yang tidak saling menguntungkan dan tidak saling merugikan satu sama lain

- Mutualisme yaitu hubungan antara dua jenis makhluk hidup yang saling menguntungkan, bila keduanya berada pada satu tempat akan hidup layak tapi bila keduanya berpisah masing-masing jenis tidak dapat hidup layak,

- Parasitisme yaitu hubungan yang hanya menguntungkan satu jenis makhluk hidup saja, sedangkan jenis lainnya dirugikan,

- Predatorisme yaitu hubungan pemangsaan antara satu jenis makhluk hidup terhadap makhluk hidup yang lain,

- Kooperasi adalah hubungan antara dua makluk hidup yang bersifat saling membantu antara keduanya

- Kompetisi adalah bentuk hubungan yang terjadi akibat adanya keterbatasan sumber daya alam pada suatu tempat

- Komensalisme adalah hubungan antara dua makhluk hidup, makhluk hidup yang satu mendapat keuntungan sedang yang lainnya tidak dirugikan,

- Antagonis adalah hubungan dua makhluk hidup yang bersifat permusuhan. 


\section{STUDI KASUS}

\subsection{Artikel Jurnal 1}

Judul

: Fisheries Management under Ecological Interdependence: The Case of European Hake and Blue Whiting Fishery

Penulisa : Marcos Pérez-Pérez, M. Dolores Garza-Gil, Manuel Varela Lafuente Tahun : 2017

Hasil Review :

Berdasarkan jurnal tersebut mengungkapkan bahwa dalam perikanan tangkap dimana terdapat kesaling bergantungan ekologi yang meningkat antara dua atau lebih spesies target, sehingga untuk melakukan penangkapan perlu adanya manajemen tangkap karena tangkapan satu spesies akan mempengaruhi tidak hanya pada satu spesies itu saja namun berdampak pula pada alam dan spesies yang lainnya, karena semua itu saling bergantungan. Tujuan dari penangkapan tersebut yaitu memberikan manfaat bagi masyarakat dalam memenuhi kebutuhan hidupnya dan proses pemanenan harus memperhatikan aspek lingkungan serta keberlanjutan spesies (Didiharyono dkk, 2021).

Adapun tujuan dari jurnal ini yaitu untuk mengembangkan model preypredator (mangsa-pemangsa) pada dua spesies utama yang tertangkap oleh kapal perikanan Uni Eropa di daerah penangkapan ikan Uni Eropa. Model yang digunakan adalah model Lotka-Volterra. Untuk menganalisis pengelolaan perikanan multispesises dan pemecahan model yang diterapkan sehingga diperoleh nilai biomassa dan hasil tangkapan dengan menganalisis MSY (Maximum Suistanable Yield) di perairan tersebut.

Hasil yang didapat yaitu bahwa MSY pemangsa lebih tinggi daripada MSY mangsa yang lebih rendah. Analisis sensitivitas hasil menunjukan bahwa tingkat biomassa dari kedua spesies menurun dengan meningkatnya hasil tangkapan oleh nelayan diperairan tersebut.

\subsection{Artikel Jurnal 2}

Judul

: Analisis Model Mangsa Pemangsa Pada Penangkapan Ikan yang Dipengaruhi Oleh Konservasi

Penulis : Eka Yuniarti dan Abadi 
Tahun : 2013

Hasil Review :

Berdasarkan jurnal tersebut mengungkapkan bahwa dalam jurnal tersebut dibentuk suatu model mangsa pemangsa pada kegiatan penagkapan ikan yang dipengaruhi konservasi, sehingga daerah penangkapan dibagi menjadi daerah bebas tangkap dan daerah konservasi. Model matematika yang digunakan terdiri dari tiga komponen spesies yakni populasi ikan di daerah bebas tangkap, populasi ikan di daerah konservasi dan populasi pemangsa. Kemudian ditentukan kestabilan penyelesaian sistem tersebut dengan menentukan titik kritis atau titik setimbangnya terlebih dahulu (Didiharyono, 2016). Kemudian diambil beberapa kasus yang berkaitan dengan konservasi sebagai perbandingan. Dari analisis yang telah dilakukan diperoleh perubahan keadaan setimbang populasi ikan di daerah konservasi dan populasi pemangsa.

Hasil analisis dari jurnal tersebut diperoleh bahwa semakin kecil angka migrasi dari daerah bebas tangkap ke daerah konservasi, maka jumlah pemangsa akan menurun. Hal ini disebabkan semakin sedikit populasi ikan di daerah bebas tangakap akibat migrasi ikan mangsa ke daerah koservasi semakin banyak, sedangkan migrasi ke daerah bebas tangkap semakin sedikit, sehingga berkurang pula populasi pemangsa akibat berkurangnya mangsa di daerah bebas tangkap tersebut. sedangkan populasi di daerah konservasi semakin meningkat.

\subsection{Artikel Jurnal 3.}

Judul

: Stability Analysis Of Two Predators And One Prey Population Model With Harvesting In Fisheries Management

Penulis : Didiharyono, Syamsuddin Toaha, Jeffry Kusuma, \& Kasbawati Tahun : 2021

Hasil Review :

Kajian dalam paper tersebut yaitu hubungan interaksi antara populasi mangsa pemangsa pada populasi perikanan yang dimodelkan secara matematis dan terjadi usaha pemanenan $(E)$ pada ketiga populasi mangsa pemangsa. Berdasarkan analisis diperoleh titik keseimbangan yang stabil asimptotik yang didasarkan pada kriteria uji kestabilan Hurwitz dan diperoleh keuntungan maksimal $(\pi)$ yang didasarkan penerimaan total (TR) dan biaya total (TC) dari kegiatan pemanenan pada ketiga 


\section{$\underline{\text { Artikel Ilmiah Nasional }}$}

populasi mangsa pemangsa. Terakhir, dilakukan simulasi numerik untuk mengetahui berapa besar keuntungan maksimal yang diperoleh dengan asumsi awal, semakin besar kegiatan pemanenan yang dilakukan, semakin besar juga keuntungan yang diperoleh.

Hasil analisis menunjukan bahwa model mangsa pemangsa pada populasi perikanan dan pemanenan pada ketiga populasi mangsa pemangsa diperoleh titik keseimbangan yang stabil asimptotik yang didasarkan pada kriteria uji kestabilan Hurwitz. Dan juga diperoleh keuntungan maksimal $(\pi)$ dari kegiatan usaha pemanenan pada ketiga populasi mangsa pemangsa. Besarnya keuntungan maksimal yang diperoleh didasarkan pada besarnya usaha pemanenan yang dilakukan. Semakin banyak kegiatan pemanenan yang dilakukan terhadap populasi mangsa pemangsa tersebut, maka semakin banyak keuntungan yang diperoleh. Agar populasi tetap terjaga atau tetap lestari maka kegiatan pemanenan $(E)$ berdasarkan aturan yang ditetapkan dan tidak melakukan pemanenan secara berlebihan (over harvesting) yang dapat menyebabkan rusaknya ekosistem populasi mangsa pemangsa.

\section{PENUTUP}

\subsection{Kesimpulan}

Predasi merupakan hubungan antara predator (pemangsa) dan prey (mangsa). Pada predasi sendiri terdapat dua model yang mendeskripsikan interaksi dua spesies terdiri dari predator dan prey merupakan model predator-prey. Model predator- prey sederhana ini diperkenalkan Lotka- Voltera yang kemudian di modifikasi oleh Leslie Gower. Hubungan antar spesies dapat dikelompokkan menjadi netralisme, mutualisme, parasitisme, predatorisme, kooperasi, kompetisi, komensalisme, dan antagonis.

\subsection{Saran}

1. Sebagaimana tugas seorang pelajar ataupun mahasiswa adalah mensukseskan dan mensejahterakan masa depan dengan diawali belajar dengan sungguh- sungguh untuk mencapainya.

2. Membaca dengan memahami materinya akan lebih baik daripada menghafalkanya.

3. Jangan hanya terfokus pada satu referensi tapi perbanyaklah referensi untuk memperkaya materi dari sumber-sumber lain. 


\section{DAFTAR PUSTAKA}

Campbell, N. A. dan Reece, J. B. (2004). Biology Fifth Edition. Pearson Education, Inc. United State.

Danca, M., Codreanu, S. dan Bako, B. (1997). Detailed analysis of a nonlinear preypredator model. Journal of Biological Physics 23:11-20.

Dwaradi, H. (2011). Analisis Model Mangsa-pemangsa Michaelis-Menten dengan Pemanenan pada Populasi Mangsa. Skripsi tidak dipublikasikan. Institut Pertanian Bogor. Bogor.

Dwidjoseputro, D. (1991). Ekologi Manusia Dengan Lingkungannya. Erlangga. Jakarta.

Didiharyono, D. (2016). Stability analysis of one prey two predator model with Holling type III functional response and harvesting. Journal of Math Sciences, 1(2 October), 5054.

Didiharyono, D., \& Irwan, M. (2019). Analisis Kestabilan dan Usaha Pemanenan Model Predator Prey Tipe Holling III dengan Keuntungan Maksimum. Jurnal Varian, 2(2), 55-61.

Didiharyono, D., Toaha, S., \& Kusuma, J. (2021, November). Stability analysis of two predators and one prey population model with harvesting in fisheries management. In IOP Conference Series: Earth and Environmental Science (Vol. 921, No. 1, p. 012005). IOP Publishing.

Edwards, C. H. dan Penney, D. E. (2008). Elementary Differential Equations Sixth Edition. Pearson Education, Inc. New Jersey.

Eka Y., dan Abadi. (2013). Analisis Model Mangsa Pemangsa Pada Penangkapan Ikan yang Dipengaruhi Oleh Konservasi. Jurnal Mahasiswa Unesa. 2(1):1- 5.

Iswanto, R.J. (2012). Pemodelan Matematika: Aplikasi dan Terapan. Graha Ilmu. Yogyakarta.

Logan, D. (2011). A first Course in Differentian Equations. Lincoln: Springer Science Bussiness Media.

Luckinbill, L. S. (1973). Coexistence in laboratory populations of paramecium aurelia and its predator didinium nasutum. Journal of Ecology 54(6):1320-1327.

Marcos Pérez-Pérez, M. Dolores Garza-Gil, Manuel Varela-Lafuente. (2017). Fisheries Management under Ecological Interdependence: The Case of European Hake and Blue Whiting Fishery. Journal of Natural Resources. 8(1): 569- 581.

Ramlawati., H., Saenab, S., \&Yunus, S. (2017). Ekologi. Mata Pelajaran IPA. Kementrian Pendidikan dan Kebudayan, DirektoratJendral Guru dan Tenaga Kependidikan.

Sahamony, P. Sianturi, Jaharuddin. (2016). Analisis Bifurkasi Model Leslie Gower Tipe Holling Ii Dengan Waktu Tunda. JMA 15(1): 33-44.

Toaha, S. (2013). Pemodelan Matematika dalam Dinamika Populasi. Dua satu Makassar 